\title{
MODEL PEMBELAJARAN MITIGASI BENCANA TANAH LONGSOR DI SEKOLAH DASAR LERENG GUNUNG RINJANI
}

\author{
Syahrial A. ${ }^{1)}, K^{\prime} o s i m^{1}$, ( Wayan Gunada1), Luh Putu Utari²) \\ 1) Program Studi Pendidikan Fisika, FPMIPA, Universitas Mataram, Mataram, NTB \\ 2)SD Negeri 1 Sembalun, Dinas Pendidikan Lombok Timur, Mataram, NTB \\ Corresponding author: Syahrial A. \\ E-mail : syahrial_ayub@unram.ac.id
}

Diterima 17 Oktober 2021, Disetujui 06 November 2021

\begin{abstract}
ABSTRAK
Artikel ini adalah salah satu hasil penelitian pengembangan model pembelajaran mitigasi bencana bagi guru dan peserta didik di sekolah dasar. Hasil ini diterapkan didaerah pegunungan, pesisir dan kota. Sampel daerah pegunungan adalah SD Negeri 1 Sembalun yang terletak di lereng gunung Rinjani Lombok Timur, NTB. Penerapannya diawali dengan modeling pembelajaran mitigasi bencana tanah longsor, struktur pembelajaran mitigasi bencana dikaitkan dengan modeling, teknik moderasi untuk mengungkap tanggapan dan pendapat guru, peer teaching oleh guru dan terakhir monitoring, observasi, evaluasi dan refleksi. Hasil penelitian merekomendasikan model pembelajaran mitigasi bencana mempunyai 3 tahapan pokok pembelajaran yaitu kegiatan awal, kegiatan inti dan kegiatan pemantapan. Setiap kegiatan memiliki tujuan pembelajaran yang harus dicapai dengan berbagai alternatif kegiatan yang dapat dipilih guru. Hasilnya $100 \%$ guru memiliki keinginan untuk melaksanakan model pembelajaran mitigasi bencana yang berbasis peserta didik, 91,67 \% model pembelajaran mitigasi bencana tepat untuk memenuhi kebutuhan peserta didik dalam meningkatkan kesadaran bencana di sekolah dan masyarakat dan $33,33 \%$ guru mengharapkan tambahan materi untuk buku model pembelajaran mitigasi bencana untuk guru sekolah dasar. Tambahan itu berupa lagu-lagu tentang bencana dan dikemas dengan kreatif supaya peserta didik senang dan lebih cepat mengerti.
\end{abstract}

Kata kunci: model pembelajaran mitigasi bencana; tanah longsor; sekolah dasar.

\begin{abstract}
This article is one of the results of research on the development of disaster mitigation learning models for teachers and students in primary schools. These results are applied in mountainous, coastal and urban areas. The sample of mountainous areas is SD Negeri 1 Sembalun which is located on the slopes of Mount Rinjani, East Lombok, NTB. Its application begins with modeling of landslide disaster mitigation learning, disaster mitigation learning structure associated with modeling, moderation techniques to reveal teacher responses and opinions, peer teaching by teachers and finally monitoring, observation, evaluation and reflection. The results of the study recommend that the disaster mitigation learning model has 3 main learning stages, namely initial activities, core activities and stabilization activities. Each activity has learning objectives that must be achieved with various alternative activities that the teacher can choose. The result is that $100 \%$ of teachers have a desire to implement student-based disaster mitigation learning models, $91.67 \%$ of disaster mitigation learning models are appropriate to meet the needs of students in increasing disaster awareness in schools and communities and $33.33 \%$ of teachers expect additional material for books. disaster mitigation learning model for primary school teachers. The additions are in the form of songs about disasters and packaged creatively so that students are happy and understand more quickly.
\end{abstract}

Keywords: disaster mitigation learning model; landslide; primary school.

\section{PENDAHULUAN}

Bencana adalah peristiwa atau rangkaian peristiwa yang mengancam dan mengganggu kehidupan dan penghidupan masyarakat yang disebabkan, baik oleh faktor alam dan/atau faktor non alam maupun faktor manusia sehingga mengakibatkan timbulnya korban jiwa manusia, kerusakan lingkungan, kerugian harta benda, dan dampak psikologis. Periode Januari sampai dengan Oktober telah terjadi 2045 kali terjadi bencana alam di Indonesia (BNPB, 2021). Bencana terjadi tibatiba dan tidak diketahui dimana terjadinya. Sampai saat ini tidak ada satu alatpun yang mampu memprediksi ataupun mengetahui kapan dan dimana bencana terjadi, olehkarena 
itu yang dapat kita lakukan hanya bersiap menghadapi bencana. Kesiapsiagaan dan mitigasi bencana menjadi hal penting untuk mengurangi risiko bencana seperti korban jiwa, harta benda dan dampak psikologis. Pengetahuan dan keterampilan kesiapsiagaan dan mitigasi bencana akan memunculkan kesadaran bencana yang diwujudkan dalam bentuk perilaku sadar bencana pada masyarakat (Agustiana, T., 2013). Peristiwa bencana yang selama ini terjadi lebih sering disebabkan kurangnya kesadaran dan pemahaman pemerintah maupun masyarakat terhadap ancaman/bahaya dan kerentanan/kelemahan menghadapi bencana alam (A. Rusilowati, 2012). Berdasarkan UU No.24/2007 tentang penanggulangan bencana, kesiapsiagaan adalah serangkaian kegiatan yang dilakukan untuk mengantisipasi bencana melalui pengorganisasian serta melalui langkah yang tepat guna dan berdaya guna. Kesiapsiagaan adalah suatu persiapan untuk perencanaan tentang tindakan pencegahan terhadap kejadian bencana dan kemungkinan kejadian bencana. Perencanaan yang dilakukan berdasarkan kepada semua kebutuhan yang dibutuhkan dalam keadaan darurat yang didukung oleh sumber daya yang ada untuk dapat memenuhi kebutuhan tersebut. Manfaat dari tindakan pencegahan ini salah satunya yaitu dapat mengurangi dampak buruk dari suatu ancaman (DAPS-SEQIP, 2009). Menurut Disaptono (2005) kesiapsiagaan merupakan tindakan yang dapat membuat semua elemen seperti pemerintah, organisasi, masyarakat, dan individu untuk mampu menanggapi suatu situasi bencana secara cepat dan tepat guna. Tindakan kesiapsiagaan terdiri dari penyusunan rencana tentang penanggulangan bencana, pemeliharaan sumber daya yang ada dan pelatihan terhadap masyarakat atau personil yang bertujuan untuk dapat mengurangi dampak buruk yang diakibatkan oleh bencana tersebut. Mitigasi bencana adalah serangkaian upaya untuk mengurangi risiko bencana, baik melalui pembangunan fisik maupun penyadaran dan peningkatan kemampuan menghadapi ancaman bencana (Pasal 1 ayat 6 PP No 21 Tahun 2008 Tentang Penyelenggaraan Penanggulangan Bencana).

Pemahaman mitigasi bencana pada siswa pendidikan dasar merupakan salah satu solusi yang perlu dilakukan di Indonesia, guna mengurangi terjadinya bencana yang mengakibatkan korban jiwa pada anak-anak di bawah umur 15 tahun. Jumlah kematian anak anak yang sangat tinggi serta mengalami stress dan trauma sebenarnya kesemua ini tidak akan terjadi, apabila dari awal anak-anak dibentuk dengan memiliki konsep diri positif dalam memahami mitigasi bencana. Anak-anak yang memiliki pengetahuan tentang cara penyelamatan diri dalam menghadapi bahaya, akan menjadi lebih mampu dan memiliki kepercayaan diri yang positif tanpa merasa ketakutan dan stress (Djamarah, 2005). Salah satu cara untuk menanamkan pemahaman mitigasi bencana adalah melalui pendidikan mitigasi bencana di sekolah dasar (Ibrahim, 2000). Pendidikan akan memberikan pengetahuan, pemahaman dan keterampilan berprilaku dalam mencegah, mendeteksi, mengantisipasi bencana secara efektif dapat ditransformasikan, disosialisasikan melalui pendidikan IPA yang secara khusus membahas mengenai isu-isu masalah sains. Pendidikan mitigasi bencana yang dikembangkan terintegrasi dalam matapelajaran IPA di sekolah dasar sehingga walaupun dikurikulum belum tertulis secara implisit tetapi pendidikan mitigasi bencana di sekolah dasar tetap bisa dilakukan. Hal ini memberikan angin segar bagi peserta didik di sekolah dasar terutama lokasi sekolahnya berada di daerah rawan bencana seperti SD Negeri 1 Sembalun. Sekolah ini adalah salah satu sekolah yang terdampak saat gempa Lombok tahun 2018. Disamping itu, sekolah ini juga rawan terhadap bencana lain seperti letusan gunung berapi, tanah longsor dan banjir bandang. Inilah yang menjadikan alasan peneliti untuk menerapkan salah satu model pembelajaran mitigasi bencana dan mengungkapkan respon guru terhadap penerapan ini. Permasalahannya adalah : (a) bagaimana contoh kurikulum matapelajaran IPA bermuatan mitigasi bencana?, (b) bagaimana bentuk rencana pelaksanaan pembelajaran mitigasi bencana yang terintegrasi dengan matapelajaran IPA?, dan (c) bagaimana respon guru terhadap model pembelajaran mitigasi bencana di sekolah dasar?

\section{METODE PENELITIAN}

Penelitian ini sebenarnya telah dilakukan secara kontinu lebih awal selama tim peneliti bergabung di proyek peningkatan kesiapsiagaan bencana bagi peserta didik di sekolah dasar kerjasama Indonesia Jerman yang disebut DAPS (Disaster Awareness in Primary School) dari tahun 2007 sampai dengan 2013. Hasil penerapan model yang telah dirancang peneliti di berbagai tempat ini di evaluasi dan direfleksikan pada penerapan berikutnya, sehingga didapatkan model pembelajaran mitigasi bencana tanah longsor. Penelitian ini adalah penelitian pengembangan yang dilakukan 6 tahap, yaitu: (1) Reseach and information collecting, (2) Planning, (3) Develop 
preliminary form of product, (4) Prelimary field testing, (5) Main Product revision, (6) Operational field testing and final product revision (Sugiyono,2017). Saat ini berada di tahap (4) yaitu ujicoba lapangan pendahuluan. Ujicoba lapangan pendahuluan ini dilakukan di 3 lokasi, yaitu pegunungan, pesisir dan kota. $\mathrm{Di}$ pegunungan di ambil sampel SD Negeri 1 Sembalun yang berada di lereng gunung Rinjani Lombok Timur, NTB. Langkah langkah yang ditempuh di tahap ini adalah, (a) langkah awal yang dilakukan adalah memberikan contoh nyata kepada guru pembelajaran mitigasi di sekolah dasar. Salah seorang tim menjadi guru yang mengajarkan pembelajaran mitigasi bencana sedangkan guru-guru menjadi peserta didik. Topik pembelajaran yang diambil adalah "mengenal cara-cara menghadapi bencana tanah longsor", (b) menjelaskan dan mendiskusikan struktrur pembelajaran mitigasi bencana yang dikaitkan dengan pembelajaran mitigasi bencana mengenal cara-cara menghadapi bencana tanah longsor, (c) mengungkapkan tanggapan dan pendapat guru terhadap pembelajaran mitigasi bencana dan struktur pembelajaran dengan menggunakan teknik moderasi, (d) peer teaching mitigasi bencana oleh guru, (e) observasi, evaluasi dan refleksi terhadap peer teaching yang dilakukan oleh guru. Instrumen penelitian berupa kuesioner guru dan lembar pengamatan pembelajaran mitigasi bencana. Kuesioner guru berisi sistem penelitian, sistem peralatan mitigasi bencana, dan buku model pembelajaran mitigasi bencana. Lembar pengamatan pembelajaran mitigasi bencana berisi langkah-langkah yang dilakukan guru di kegiatan awal, inti dan pemantapan. Data yang diperoleh dari instrumen penelitian yang disebarkan dianalisis secara kuantitatif dan kualitatif. Analisis kuantitatif menampilkan prosentase jawaban-jawaban guru terhadap kuesioner yang diberikan sedangkan analisis kualitatif adalah komentar, analisa dan pembahasan hasil kuesioner, dan model pembelajaran mitigasi bencana yang kemudian diinterpretasikan sesuai tujuan penelitian. Pengembangan model pembelajaran mitigasi bencana tanah longsor dengan topik "mengenal cara-cara menghadapi bencana alam tanah longsor" dilakukan dengan tahapan: (1) analisis kurikulum IPA sekolah dasar, mengkaji teori yang terkait, dan analisis dokumen lain yang terkait; (2) analisis kebutuhan (need assessment) berkaitan dengan penyusunan model mitigasi bencana tanah longsor; (3) penyusunan draft model mitigasi bencana tanah longsor dalam pembelajaran IPA yang sifatnya hipotetik dan siap untuk diujicobakan; (4) penyusunan instrumen untuk uji coba model dan bahan ajar; serta (6) uji coba dengan cara implementasi draft model di sekolah, yaitu SD Negeri 1 Sembalun. Hasil akhir penelitian pengembangan ini diharapkan : (1) peta kompetensi dasar IPA yang mengandung mitigasi bencana, (2) deskripai analisis kebutuhan peserta didik, guru dan kepala sekolah dalam kaitan pengembangan model mitigasi bencana dalam pembelajaran IPA, dan (3) seperangkat model mitigasi bencana dalam pembelajaran IPA. Pada artikel ini, baru bisa dipaparkan hasil penelitian di satu lokasi saja, yaitu SD $N$ 1 Sembalun dengan model pembelajaran mitigasi bencana tanah longsor.

\section{HASIL DAN PEMBAHASAN Hasil Penelitian \\ Hasil analisis kurikulum IPA mendapatkan standar kompetensi dan kompetensi dasar yang berkaitan dengan mitigasi bencana tanah longsor dengan topik "mengenal cara-cara menghadapi bencana alam tanah longsor" terdapat di kelas IV yaitu:}

Standar kompetensi : menjelaskan pentingnya upaya keseimbangan dan pelestarian sumber daya alam di lingkungannya.

Kompetensi Dasar : melakukan kegiatan untuk pelestarian sumber daya alam bersama orang orang di lingkungannya.

Dari standar kompetensi dan kompetensi dasar di rumuskan indikator dan tujuan pembelajarannya, yaitu

Indikator : (1) menjelaskan tingkat risiko (potensi) terjadinya tanah longsor, (2) menjelaskan upaya mengurangi risiko terjadinya tanah longsor, (3) mengidentifikasi tanda-tanda awal terjadinya tanah longsor.

Tujuan Pembelajaran : setelah pembelajaran ini selesai, peserta didik diharapkan dapat: (1) menjelaskan pengertian ancaman tanah longsor, (2) menjelaskan pengertian kerentanan mengalami tanah longsor, (3) menjelaskan pengertian kemampuan menghadapi tanah longsor, (4) menjelaskan upaya mengurangi risiko terjadinya tanah longsor, dan (5) mengidentifikasi tanda-tanda awal terjadinya tanah longsor. Berikut kegiatan belajar mengajar yang telah disusun: 
Tabel 1. Kegiatan Belajar Mengajar Mitigasi

\begin{tabular}{|c|c|c|}
\hline Interaksi & $\begin{array}{c}\text { Tahap } \\
\text { Pembelajaran }\end{array}$ & $\begin{array}{l}\text { Alat Bantu } \\
\text { Belajar }\end{array}$ \\
\hline & 1. Kegiatan Awal & \\
\hline$G-M$ & $\begin{array}{l}\text { a. Siswa diminta } \\
\text { bercerita tentang } \\
\text { pengalaman atau } \\
\text { informasi yang } \\
\text { diketahui atau } \\
\text { membaca berita } \\
\text { koran tentang } \\
\text { bencana alam. }\end{array}$ & $\begin{array}{l}\text { Foto-foto } \\
\text { tanah longsor } \\
\text { (Gambar 1) }\end{array}$ \\
\hline$M-M$ & $\begin{array}{l}\text { b. Siswa diminta } \\
\text { mendiskusikan } \\
\text { apa yang telah } \\
\text { mereka dengar } \\
\text { untuk } \\
\text { mengindentifikasi } \\
\text { berbagai bencana } \\
\text { alam. }\end{array}$ & Papan tulis \\
\hline$M-M$ & $\begin{array}{l}\text { c. Mereka juga } \\
\text { diminta } \\
\text { mendiskusikan } \\
\text { mengenai } \\
\text { kemungkinan } \\
\text { dampak bencana } \\
\text { alam tersebut } \\
\text { bagi manusia } \\
\text { maupun } \\
\text { lingkungannya. }\end{array}$ & \\
\hline$M-M$ & $\begin{array}{l}\text { d. Hasil diskusi ini } \\
\text { ditulis di papan } \\
\text { tulis }\end{array}$ & \\
\hline$G-M$ & $\begin{array}{l}\text { e. Guru } \\
\text { menginformasikan } \\
\text { bahwa pertemuan } \\
\text { hari ini, kita akan } \\
\text { membahas } \\
\text { tentang salah } \\
\text { satu bencana } \\
\text { alam tadi, yaitu } \\
\text { Bagaimana cara- } \\
\text { cara menghadapi } \\
\text { bencana alam } \\
\text { tanah longsor? }\end{array}$ & \\
\hline
\end{tabular}

\begin{tabular}{|c|c|c|}
\hline & $\begin{array}{l}\text { 2. Kegiatan Inti } \\
\text { Kegiatan 1: } \\
\text { Menjelaskan tingkat } \\
\text { risiko (potensi) } \\
\text { terjadinya tanah } \\
\text { longsor. }\end{array}$ & $\begin{array}{l}\text { Gambar- } \\
\text { gambar } \\
\text { (kartun) } \\
\text { bencana } \\
\text { alam } \\
\text { tanah }\end{array}$ \\
\hline $\mathrm{G}$ & $\begin{array}{l}\text { a. Guru } \\
\text { mengelompokkan } \\
\text { siswa menjadi } \\
\text { beberapa kelompok }\end{array}$ & $\begin{array}{l}\text { longsor } \\
\text { Gambar } \\
2 \mathrm{a}, 2 \mathrm{~b}, 2 \mathrm{c} \\
\text { dan 2d }\end{array}$ \\
\hline G & $\begin{array}{l}\text { b. Guru membagikan } \\
\text { gambar/ foto ke } \\
\text { setiap kelompok }\end{array}$ & \\
\hline$M-M$ & $\begin{array}{l}\text { c. Siswa melakukan } \\
\text { diskusi kelompok } \\
\text { untuk : menjawab } \\
\text { pertanyaan setiap } \\
\text { gambar dan } \\
\text { memberikan alasan }\end{array}$ & \\
\hline
\end{tabular}

$$
G-M
$$

d. Siswa diminta berdiskusi hasil pengamatan dalam Kelompoknya masing-masing.

e. Siswa wakil dari

Kelompok kelompoknya menjelaskan ke kelompok lainnya.

1) Menjelaskan

Ancaman atau

bahaya

terjadinya tanah longsor daň fotofoto dan gambargambar tersebut

2) Menjelaskan

Kerentanan terjadinya tanah longsor daň fotofoto dan gambargambar tersebut

3) Menjelaskan Kemampuan akan terjadinya tanah longsor dan foto-foto dan gambar-gambar tersebut

f. Selanjutnya guru menanyakan hubungan ancaman dengan dampak terjadinya tanah longsor?

Besar ancaman tidak sebanding risiko

g. Selanjutnya guru menanyakan hubungan kerentanan dengan dampak terjadinya tanah longsor?

Besar kerentanan sebanding langsung besar resiko

h. Selanjutnya guru

menanyakan

hubungan

kemampuan dengan dampak terjadinya tanah longsor?

Besar kemampuan berbanding terbalik resiko

i. Siswa melakukan

$\mathrm{G}-\mathrm{M}$ diskusi dengan

bimbingan Guru untuk tentang pengertian risiko yang dihubungkan dengan ancaman, kerentanan, kemampuan terjadinya tanah longsor. 


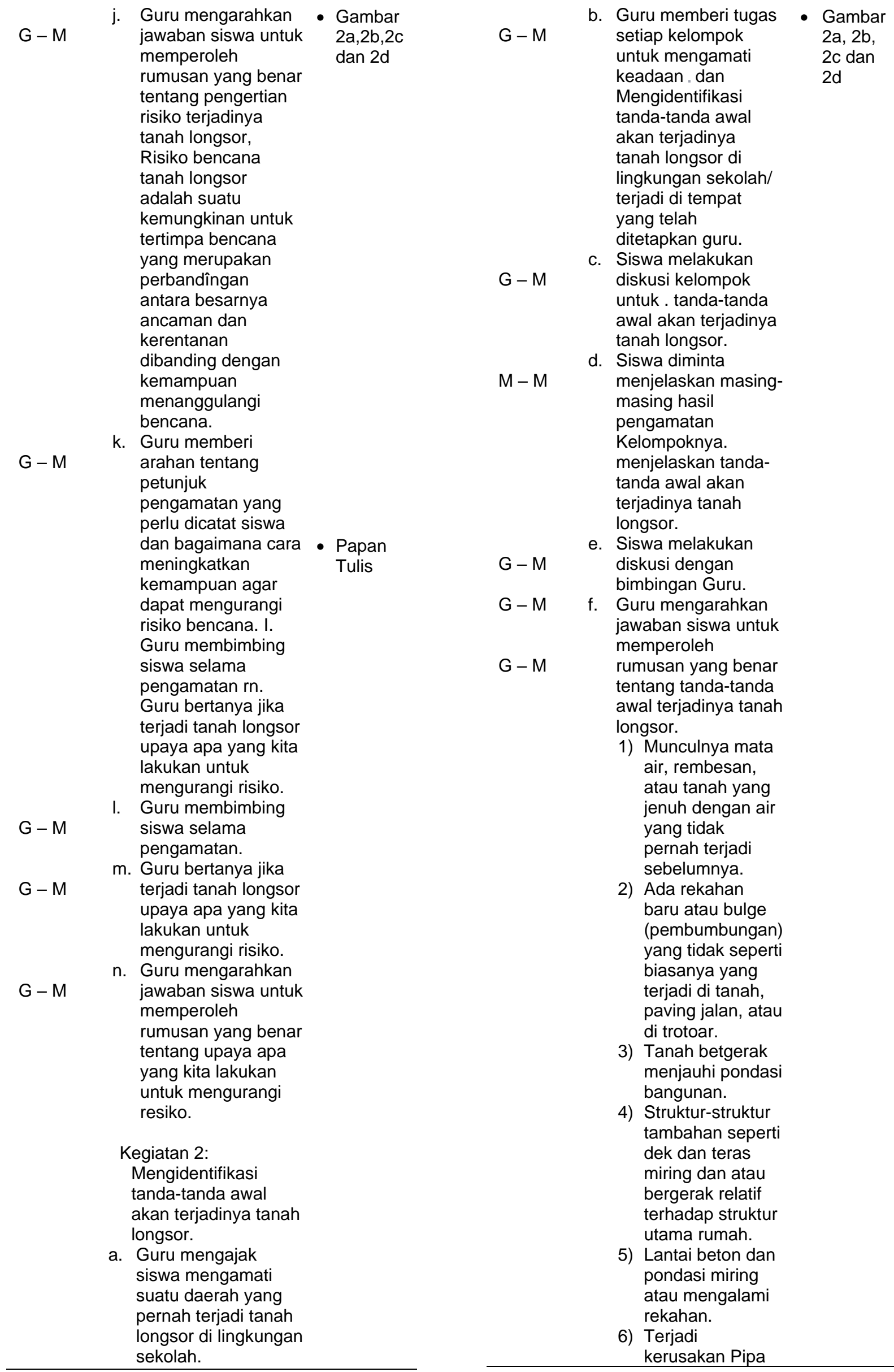


air dan fasilitas bawah tanah.

7) Tiang telepon, pohon, dinding penahan, atau pagar mengalami sedikit atau banyak pergeseran sehingga miring.

8) Terjadi pergeseran pada kusen pintu.

\begin{tabular}{llll}
\hline & 3. $\begin{array}{l}\text { Kegiatan } \\
\text { Pemantapan }\end{array}$ & \\
$\mathrm{G}-\mathrm{M}$ & a) & $\begin{array}{l}\text { Guru menugaskan } \\
\text { siswa membaca } \\
\text { tentang tanah } \\
\text { longsor dari buku } \\
\text { bacaan atau media } \\
\text { cetak yang terjadi di }\end{array}$ & $\begin{array}{l}\text { - Bacaan } \\
\text { ringkas } \\
\text { tentang } \\
\text { tanah } \\
\text { lndongsor }\end{array}$ \\
& lonia. & \\
& buru meminta untuk & \\
& merangkum bacaan & \\
\hline
\end{tabular}

Berikut adalah gambar-gambar yang digunakan dalam pembelajaran mitigasi bencana dengan topik mengenal cara-cara menghadapi bencana tanah longsor:
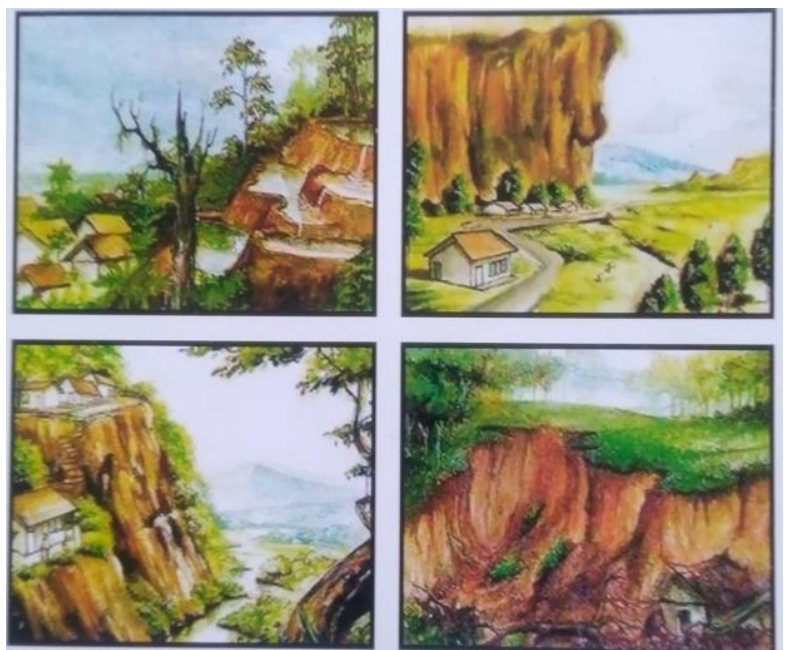

Gambar 1. Risiko tanah longsor

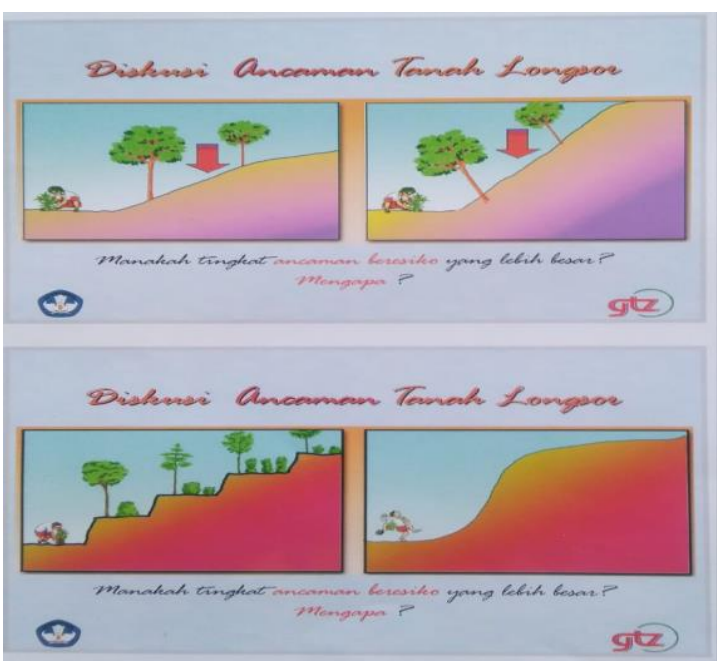

Gambar 2a. Diskusi 1 ancaman tanah longsor

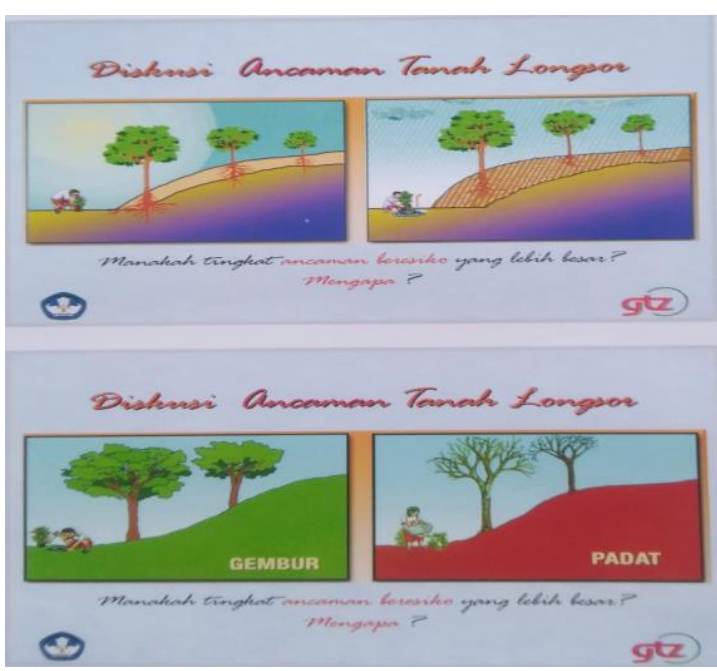

Gambar 2b. Diskusi 2 ancaman tanah longsor

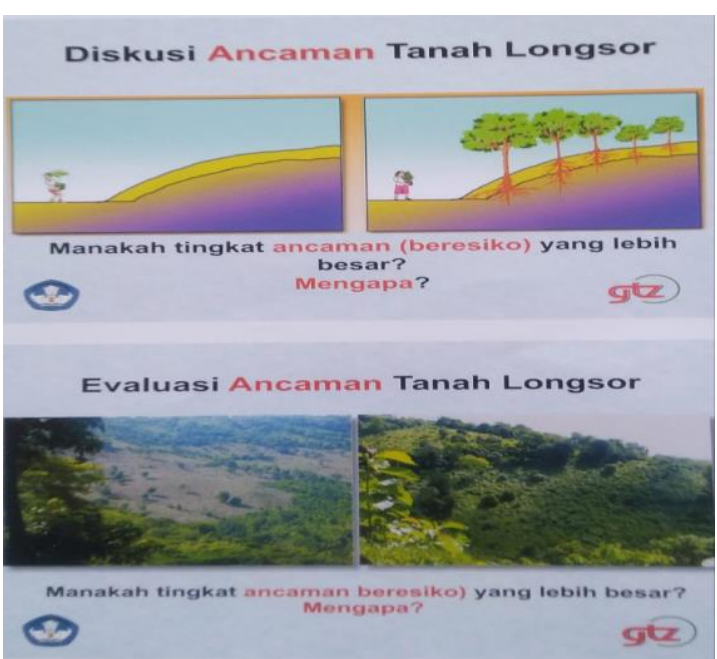

Gambar 2c. Diskusi 3 ancaman tanah longsor 


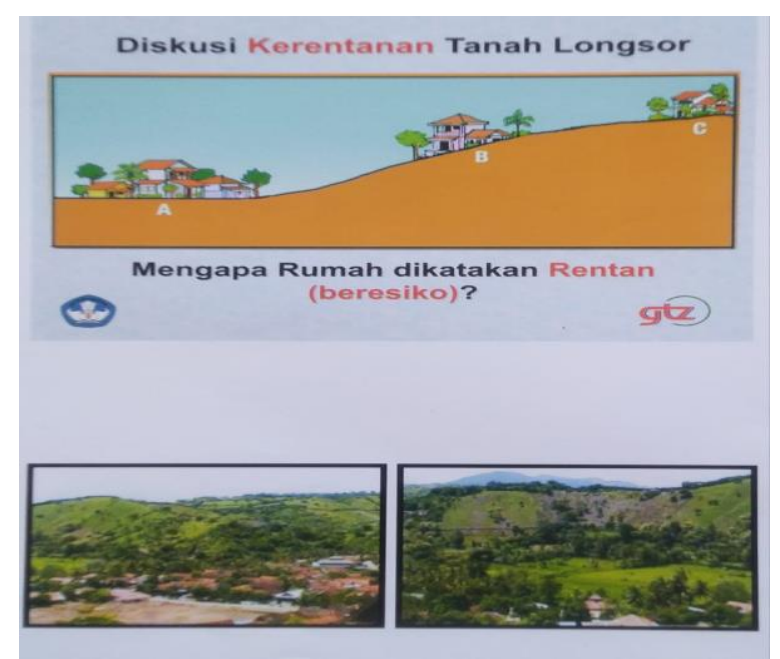

Gambar 2d. Diskusi 4 ancaman tanah longsor

Tanggapan dan pendapat guru mengenai pembelajaran mitigasi bencana di SD Negeri 1 Sembalun adalah: (1) Tanggapan dan pendapat guru mengenai materi model pembelajaran mitigasi bencana (MPMB) dan struktur pembelajaran mitigasi bencana (SPMB) dan alokasi waktu yang tersedia untuk setiap kegiatan pembelajaran mitigasi bencana.

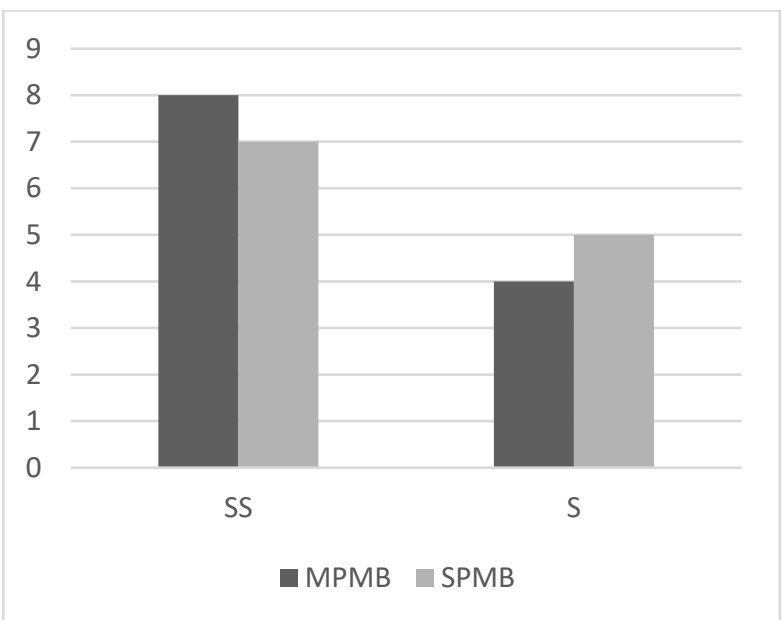

Gambar 3. Tanggapan guru terhadap MPMB dan SPMB

Gambar 3 memperlihatkan 8 dari 12 orang guru $(66,67 \%)$ sangat setuju dengan model pembelajaran mitigasi bencana dan 7 dari 12 orang guru sangat setuju $(58,33 \%)$ dengan struktur pembelajaran mitigasi bencana. Berlandaskan pertanyaan (1) di atas, tim melanjutkan pertanyaan berikutnya yaitu apakah anda memiliki keinginan untuk melaksanakan model pembelajaran mitigasi bencana. Hasilnya dapat dilihat pada tabel 3 berikut ini: $\frac{\text { Tabel 3. Tanggapan guru terhadap SPMB }}{\text { Ya Tidak Kosong }}$

Apakah Anda

memiliki keinginan

untuk

melaksanakan

model

pembelajaran

mitigasi bencana?

Sangat perlu dilakukan karena mereka tinggal di

daerah rawan bencana agar dapat siaga ketika

bencana datang

Ternyata $100 \%$ guru SD N 1 Sembalun berkeinginan untuk melaksanakan model pembelajaran mitigasi bencana. Alasan dari guru adalah sangat perlu dilakukan karena mereka tinggal di daerah rawan bencana agar dapat siaga ketika bencana datang. Tabel 4 memperlihatkan tanggapan dan pendapat guru tentang materi kebencanaan yang diberikan tepat atau tidak untuk memenuhi kebutuhan peserta didik dalam meningkatkan kesadaran bencana di sekolah. Hasilnya 92\% guru menyatakan tepat untuk memenuhi kebutuhan peserta didik tentang mitigasi bencana.

Tabel 4. Tanggapan Guru terhadap Materi Kebencanaan

\begin{tabular}{|c|c|c|c|c|}
\hline & Modul & $\begin{array}{c}\mathbf{Y a} \\
\text { (org) }\end{array}$ & $\begin{array}{c}\text { Tidak } \\
\text { (org) }\end{array}$ & $\begin{array}{c}\text { Kosong } \\
\text { (org) }\end{array}$ \\
\hline \multirow{6}{*}{$\begin{array}{l}\text { Apakah } \\
\text { model } \\
\text { pembelajaran } \\
\text { mitigasi } \\
\text { bencana } \\
\text { untuk guru } \\
\text { sekolah dasar } \\
\text { tepat untuk } \\
\text { memenuhi } \\
\text { kebutuhan } \\
\text { peserta didik } \\
\text { dalam } \\
\text { meningkatkan } \\
\text { kesadaran } \\
\text { bencana di } \\
\text { sekolah dan } \\
\text { masyarakat? }\end{array}$} & $\begin{array}{l}\text { Struktur } \\
\text { pembelajaran } \\
\text { mitigasi } \\
\text { bencana }\end{array}$ & 11 & - & 1 \\
\hline & $\begin{array}{l}\text { RPP } \\
\text { pengetahuan } \\
\text { Kebencanaan }\end{array}$ & 11 & - & 1 \\
\hline & $\begin{array}{l}\text { RPP tanda- } \\
\text { tanda } \\
\text { kebencanaan }\end{array}$ & 11 & - & 1 \\
\hline & $\begin{array}{l}\text { RPP dampak } \\
\text { resiko dan } \\
\text { upaya } \\
\text { mengurangi }\end{array}$ & 11 & - & 1 \\
\hline & $\begin{array}{l}\text { RPP } \\
\text { kesiapsiagaan }\end{array}$ & 11 & - & 1 \\
\hline & $\begin{array}{l}\text { RPP prosedur } \\
\text { pertolongan } \\
\text { pertama pada } \\
\text { korban }\end{array}$ & 11 & - & 1 \\
\hline \multicolumn{2}{|c|}{$\begin{array}{l}\text { Apakah diperlukan tambahan } \\
\text { materi untuk buku model } \\
\text { pembelajaran mitigasi bencana } \\
\text { untuk guru sekolah dasar? }\end{array}$} & 4 & 3 & 5 \\
\hline \multicolumn{5}{|c|}{$\begin{array}{l}\text { Materi yang perlu ditambahkan berupa lagu-lagu tentang } \\
\text { bencana karena peserta didik sangat senang dan lebih } \\
\text { cepat mengerti. Pembelajaran mitigasi bencana juga } \\
\text { termasuk ranah kognitif tinggi dan cukup sulit bagi peserta } \\
\text { didik sehingga butuh dikemas dengan sangat kreatif dan } \\
\text { menyesuaikan jenjang. }\end{array}$} \\
\hline
\end{tabular}

Tabel 4 memperlihatkan tanggapan dan pendapat guru yang bervariasi terhadap perlu atau tidak tambahan materi di buku model pembelajaran mitigasi bencana sekolah dasar. Salah satu produk dari penelitian ini adalah buku model pembelajaran mitigasi bencana 
untuk guru sekolah dasar. Seperti pada gambar 3 berikut ini:

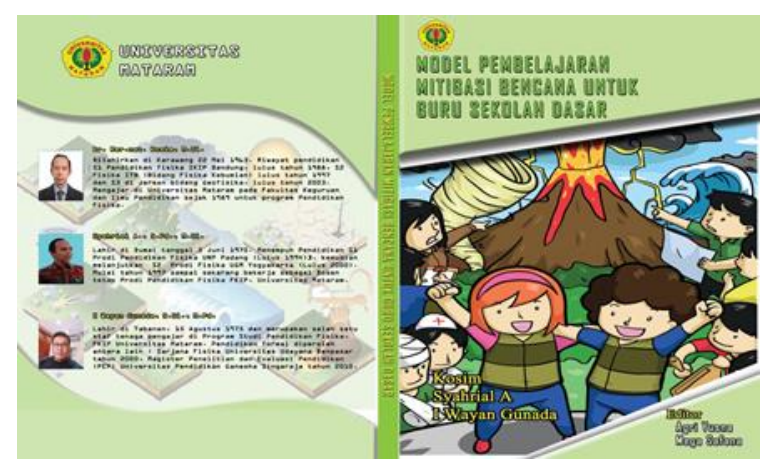

Gambar 4. Cover buku model pembelajaran mitigasi bencana untuk guru sekolah dasar

Buku ini berisi penjelasan struktur pembelajaran mitigasi bencana di sekolah dasar. Struktur ini dikembangkan dari pembelajaran penemuan (discovery learning). Berbeda dengan metode ceramah, fokus utama dari metode belajar menemukan adalah kegiatan peserta didik secara mandiri (Huda, 2013). Memang materi dipilih dan disiapkan oleh guru, tetapi peserta didik yang secara mandiri membahas suatu masalah tertentu atau guru melemparkan suatu pertanyaan tertentu di awal pembelajaran. Diskusi maupun proses kegiatan sebagian besar ditentukan sendiri oleh peserta didik, baik selama pelajaran di kelas maupun di dalam kelompok. Metode ini mempunyai beberapa keunggulan, diantaranya adalah: a) pengembangan kemandirian dan kegiatan mandiri peserta didik b) stimulasi kemampuan merencanakan, mengorganisasi dan melaksanakan kegiatan c) pengembangan tanggung jawab terhadap suatu kegiatan, dan d) pengenalan metode-metode kerja dan berpikir dalam bidang penelitian (Ayub, S.,2009). Model discovery learning berpengaruh positif terhadap hasil belajar peserta didik (Subrata, 2001). Salah satu keberhasilan utama dari praktek dan teori pengajaran abad ini adalah bahwa peserta didik dianggap sebagai mitra yang bertindak dan berpikir, dan bukan lagi diharapkan untuk menguasai dan menghafal pengetahuan yang tidak ia pahami atau tidak diterangkan secara objektif. Metode belajar menemukan memungkinkan peserta didik untuk mengalami sendiri bagaimana caranya menemukan keterkaitan keterkaitan baru dan bagaimana caranya meraih pengetahuan melalui kegiatan mandiri. Model berorientasi kepada peserta didik karena mereka yang diharapkan menemukan masalah kebencanaan, menduga, melakukan kegiatan untuk memecahkan masalah,
Menyimpulkan dan mengkomunikasikan (Suhardjo, D., 2011). Model ini menempatkan guru sebagai fasilitator dalam pembelajaran, menjelaskan hanya bila diperlukan saja (Subrata, 2001). Discovery learning adalah metode yang benar benar menjadi peserta didik pelaku dalam pembelajaran (Yerizon, 2020).

\section{UCAPAN TERIMAKASIH}

Terima kasih tim mengucapkan kepada Kementerian Pendidikan, Kebudayaan, Riset dan Teknologi yang telah membiayai penelitian ini, Universitas Mataram yang telah menfasilitasi tim dalam melakukan penelitian ini dan bapak ibu guru SD Negeri 1 Sembalun atas kesediaan dan kerjasamanya selama pelaksanaan penelitian.

\section{DAFTAR RUJUKAN}

Ayub, S. (2019). Model Pembelajaran Kesiapsiagaan Gempabumi di Sekolah Dasar. Jurnal Orbita Universitas Muhammadyah Mataram, 5(2), 65-72. doi:

https://doi.org/10.31764/orbita.v5i2.118 7

A. Rusilowati . (2012). Mitigasi Bencana Alam Berbasis Pembelajaran Bervisi Science Environment Technology and Society. Jurnal Pendidikan Fisika Indonesia. 8(1), 51-60. Retrived from. https://doi.org/10.15294/ipfi.v8i1.1994

Agustiana, T. (2013). Pengaruh Model Pembelajaran Mitigasi Bencana terhadap Pemahaman dan Ketahanmalangan Siswa. Jurnal Pendidikan dan Pengajaran. 46(2), 97105. Retrived from.

http://dx.doi.org/10.23887/jppundiksha. v46i2\%20Juli.2660

BNPB. (2021). Update Bencana Alam Tahun 2021. Jakarta: Badan Nasional Penanggulangan Bencana.

DAPS - SEQIP. (2009). Materi Pelatihan Banjir Modul I -5. Jakarta : GTZ-Dcpartcmcn Pcndidikan Nasional Direktorat Pembinaan TK clan SD.

DAPS - SEQIP. (2009). Materi Pelatihan Tanah Longsor Modul 1-5. Jakarta : GTZDepartemen Pendidikan Nasional Direktorat Pcmbinaan TK dan SD.

DAPS - SEQIP. (2009). Materi Pclatihan Gcmpa Bumi Modul 1-5. Jakarta : GTZDepartemen Pendidi kan Nasional Direktorat Pembinaan TK dan SD.

DAPS - SEQTP. (2009). Materi Pelatihan Tsunami Modul 1-5. Jakarta : GTZDepartemen Pendidikan Nasional Direktorat Pembinaan TK dan SD. 
Diposaptono S. (2005). Tsunami Mitigation Technology. Jakarta: Republic of Indonesia Maritime and Fisheries Agency Tsunami Mitigation Training Material.

Djamarah. (2005). Teachers and Students in Educative Interaction, A Psychological Theoretical Approach. Jakarta: Rineka Cipta.

Huda, M. (2013). Teaching and Learning Model Models of Methodical and Pragmatic Issues. Yogyakarta: Pustaka Pelajar.

Ibrahim, M. (2000). Problem Based Learning. Surabaya: University Pres

Sugiyono. (2017). Qualitative Quantitative Research Methods and $R$ \& $D$. Bandung: Alfabeta

Suhardjo, D. (2011). Arti Penting Pendidikan Mitigasi Bencana dalam Mengurangi Resiko Bencana. Jurnal IImiah Pendidikan Cakrawala. 2(2011), 174$188 . \quad$ Retrived from https://doi.org/10.21831/cp.v0i2.4226

Subrata. (2001). Efforts to Improve the Quality of Learning Outcomes of Elementary Students through Science Learning with Process Skills. Singaraja : LPPM STKIP Singaraja.

Yerizon, (2020). Pengembangan Perangkat Pembelajaran Berbasis Model Pembelajaran Discovery Learning pada Mataeri Matematika Berorientasi Mitigasi Bencana. Jurnal Gantang. 5(1), 69-76. Retrived from. https://doi.org/10.31629/.jg.v5i1.1898 